\title{
Chapter 6 \\ Cosmopolitan Dubai: Consumption and Segregation in a Global City
}

\author{
Delphine Pagès-El Karoui
}

\subsection{Introduction}

The tremendous rise of Dubai has been based upon aggressive strategies of post-oil diversification. To gain world recognition, Dubai has also played the card of the global city. The "corporate city" has deployed a spectacular urbanism and developed globalized landscapes to promote a new model of urbanity for an ultraconsumerist, leisure society (Kanna 2011; Davidson 2008). This rapid economic development has turned Dubai in a major hub for commerce, finance, real estate and tourism, attracting people from all over the world. Among other amazing records (largest mall, biggest airport, most luxurious hotel), Dubai now detains the one as the most cosmopolitan city, with $91 \%$ of its residents being foreign.

Interesting enough, despite the cosmopolitan turn in the social sciences (Delanty 2009), research on cosmopolitanism applied to Dubai remains underdeveloped (Bayat 2008; Masad 2008; Pagès-El Karoui 2018) when compared to the wealth of literature about other Middle East cities (see Mermier in this book) and cosmopolitan colonial Alexandria. Cosmopolitanism in Dubai is necessarily paradoxical because non-integrative: its extremely diverse society (more than 200 nationalities coexisting together) is highly marked by strong social and racial hierarchies and an intense segregation. In this Gulf monarchy ruled as an ethnocracy (Longva 2005), Emirati nationals are a small minority. The non-integrative context of migration policies (see Assaf and Thiollet in this book) sets a profound divide between nationals, who benefit from the redistribution of wealth and the welfare state, and foreigners, who are deliberately excluded from state largesse and live in a precarious and transient status (Elsheshtawy 2019; Khalaf et al. 2014). They remain "impossible

D. Pagès-El Karoui $(\bowtie)$

CERMOM, Institut National des Langues et Civilisations Orientales, IC Migrations,

Paris, France 
citizens" (Vora 2013) who can be deported at any time, whatever the length of their stay in Dubai.

Although Dubai and the UAE are increasingly promoting "tolerance" policies (Pagès-El Karoui, forthcoming 2021b), they are far from offering a real cosmopolitan political project which would imply, for instance, more integrative policies for foreigners. In such a context, the use of cosmopolitanism may be problematic when considering its normative dimension. In this case, Dubai seems to embody a superficial or pseudo-"cosmopolitanism" "which focuses only on the use of the lifestyle of other cultures to enrich one's material life without normative engagement" (Delanty 2009, 220). This idea is applied to the case of Dubai by the French geographer Denis Retaillé in his book on the places of globalization. He speaks of Dubai in terms of a "cosmopolitisme de décor" [surface cosmopolitanism] $(2012,16) . \mathrm{He}$ opposes Dubai's current "fake" cosmopolitanism with the more "authentic" and inclusive cosmopolitanism in the pre-oil period that arose out of trade and commerce around the Indian Ocean. In doing so, Retaille reproduces both the traditional debate between "superficial" and "authentic" cosmopolitanism (Molz 2011) and the common account of contemporary Dubai as ostentatious and soulless.

Provocatively, I argue that even if we reject the normative stance of traditional notions of cosmopolitanism, it is still an important heuristic concept, provided that it is empirically grounded, for thinking about diversity in multicultural cities (Pagès-El Karoui, forthcoming 2021a). Contributions to the theory of cosmopolitanism can emerge from non-normative approaches of the concept. Instead of discarding cosmopolitan as fake and superficial, how could we describe its specificities in the Gulf context? So, the real question is not whether Dubai is a cosmopolitan city but, rather, what kind of cosmopolitanism does Dubai embody?

There are two different ways of defining a cosmopolitan city. First, in a sense closely linked to cultural globalization (echoing the idea that cosmopolitanism is a cultural orientation towards globalization), a cosmopolitan city is a place open to the world, where inhabitants' practices and landscapes are strongly influenced by lifestyles, ideas, and products coming from elsewhere. This is how, in a context totally disconnected from migration, Latham (2006) has described Auckland, sharply contrasting the emergence of new bars, restaurants and cafés inspired by France or Italy to local pubs. Second, a cosmopolitan city may refer to a place people of diverse origins and backgrounds live and coexist, whatever the degree of interaction between them (although some scholars would restrict its use only to strong interactions, which is not my case). This plurality may be either the result of past or current migrations or of an internal ethnic diversity.

Dubai embodies perfectly this double meaning of the cosmopolitan city with its cosmopolitan landscapes (for instance, its bars and restaurants offering food and drinks from all over the world) and the hyper diversity of its population. To characterize Dubai's cosmopolitanism, we need to articulate it with three core concepts, consumption, segregation and globalization (which serves as a backdrop to the first two terms). In the first part of this chapter, I explore cosmopolitanism in Dubai through this nexus between consumption, segregation, and globalization. Then, through two case studies, I illustrate how the state and its corporations shape some 
cosmopolitan spaces in order to achieve the status of global city, playing with the idea of Dubai as a cosmo-polis, i.e., a city where you can encounter (and buy) the world at a local scale. I will show also how these spaces are perceived, experienced and practiced by their users, be they customers or residents. Inspired by Yasser Elsheshtawy's approach to see "behind the urban spectacle" (2013), I will analyze Dubai cosmopolitan urbanism by two ordinary spaces: Global Village and International City. ${ }^{1}$ Although they are less glittering, luxurious and visible places than the iconic architectural productions which have made Dubai famous as a global city, they both, as their names indicate, express a strong desire for globalization. Global Village is an outdoor entertainment park where you can buy products from all over the world. International City is one of the rare urban housing projects for low and middle-class foreign residents. In these two ordinary spaces, frequented mainly by non-Westerners, a kind of cosmopolitanism from below emerges, although one not exempt from tensions and contradictions as the inclusive logics of consumption coexist with the exclusive logics of segregation.

\subsection{A Consumerist and Segregated Cosmopolitanism in Global Dubai}

Cosmopolitanism in Dubai is firmly anchored in a rampant globalization. Dubai has appeared in various rankings as a global city. This chapter is less interested in the various criteria positioning Dubai in different positions of the economic hierarchies of global cities but more in how Dubai's government and companies seek to produce cosmopolitan landscapes in order to contribute to its celebrity as a global city. ${ }^{2}$ With few oil reserves, Dubai early on chose to become a hub, drawing its main resources from outside its small territory. The objective is thus to attract and retain the global middle and upper classes, as well as tourists and investors who will contribute to the city's economic prosperity. One of its challenges is to offer global landscapes for those who are eager to consume diversity. In line with the general theory of cosmopolitanism, consumption is one of the striking features of cosmopolitanism in Dubai. The other feature, segregation, is less self-evidently associated with the concept of cosmopolitanism since it seems to be in direct contradiction to term's normative dimension. Segregation, though, is an integral part of Dubai's definition of cosmopolitan, a dimension of its spatial translation also found in other non-Western cities, such as Singapore (Yeoh 2004).

\footnotetext{
${ }^{1}$ The notion of « ordinary spaces » is influenced by Robinson (2013) works on « ordinary cities », and Lamont and Aksartova (2002) on « ordinary cosmopolitanism ».

${ }^{2}$ For example, Dubai was listed in 2018 , by GaWc world city index, the famous ranking of global cities, as an Alfa+ city, the second category after Alfa++ city (New York and London). Source: https://www.lboro.ac.uk/gawc/world2018t.html
} 


\subsubsection{Cosmopolitanism as a Form of Global Consumption}

"Cities capitalize on cultural diversity to transform themselves into globalized spaces of consumption."

(Molz 2011, 38)

As a concept, cosmopolitanism is closely linked with consumption. Many scholars (Nava 2002; Binnie et al. 2006; Molz 2011) have explained how cosmopolitan encounters with difference and diversity are channeled in daily life by commodities and the process of commodification. According to Beck, "cosmopolitanism has itself become a commodity" $(2004,150)$. There are two ways to study the articulation between consumption and cosmopolitanism. The first, from above, examines how cosmopolitanism is often associated with urban spaces which are branded and planned as cosmopolitan. The second approach, from below, looks at how these places are experienced by consumers in their everyday practices. Here, I focus on "the spatialization of specific forms of 'cosmopolitan consumption' involving new arrangements of people, objects and performances by consumers who can conform to and engage with this particular vision of a "cosmopolitan lifestyle" (Binnie et al. 2006). Instead of dismissing these spaces as superficial, I argue that these spaces are crucial elements to understanding Dubai's development and cosmopolitanism.

Since Dubai is not a major oil producer (compared to Abu Dhabi), its incredible growth is mainly due to an aggressive post-oil strategy of diversification centered on trade, finance, real estate and tourism. ${ }^{3}$ Its population has grown rapidly, from 10,000 inhabitants in 1900 to 862,000 in the early 2000 s; by 2017 , its population had reached three million. The growth of the last two decades was partly due to massive construction projects - like Burj al Arab, Burj Khalifa, the Palms and the World Islands - which have contributed to making Dubai famous around the world and building up its image as a global city. Backed by major real estate development groups controlled by the Dubai government, like Nakheel, Emaar or Meraas, these iconic projects have spurred the emergence of a spectacular "new Dubai" along the Shaykh Zayed inter-city highway, which contrasts sharply with the older neighborhoods.

Dubai has never been an industrial city: it has jumped directly from a small port to a global service city based on leisure and consumption. It now epitomizes the archetypal city of consumer capitalism where consumption and leisure are central activities, playing a major role in the construction of individual and group identity.

Based upon on its history as a colonial trading port between the Middle East and the Indian Ocean, Dubai's strategy has been to develop transport infrastructures to foster commerce. Its global city position was first achieved by becoming a regional hub for air and maritime transport with gigantic ports and airports. Its famous national company, Emirates, was founded in 1985. Two years before, the first dutyfree store was opened in Dubai Airport. As part of destination branding, the Dubai

\footnotetext{
${ }^{3}$ Dubai ranked as the seventh-most touristic city in the world with 16,7 million visitors, putting it after Paris $(16,8)$ but ahead of New York $(12,3)$.
} 
Shopping Festival was created in 1996 to stimulate tourism and the retail sector. Since the opening of its first mall in 1981, al-Ghurair center in Deira, malls have flourished in Dubai. They are usually the most visited sites by tourists (among them, Dubai Mall) and act as the main gathering place on the weekends in the Emirates (Assaf 2017). Having transformed Dubai into the new mecca for shopping, malls embody the consumer culture which plays a key role in Dubai's success.

Providing world-class consumption and cultural infrastructure that facilitates global lifestyles (organic markets, yoga classes, cycle paths, etc.) is a way for Dubai to prove its standing as a global city. Parks, beaches, and restaurants offering international cuisine help to make people from around the world feel at home in Dubai. They also express the city's urbanity as a microcosm of the world. Labeling everything as "number one" or "world class" is a response to the tension between the need for generic places (see Duyvendak and Ley-Cervantes in this book) with homogenized global standards, on the one hand, and, on the other, the attempt to create special features that ensure that these places are worth visiting. This contradiction expresses the consumer logic of late capitalism, which takes advantage of difference and markets it, and, in so doing, eradicates it (Binnie et al. 2006).

As for other global metropolises, diversity has become an asset to promote the city at an international scale. For instance, on its official tourism platform, Dubai advertises itself as a "global culinary scene" with the slogan "Find the world in your plate." Here Dubai seems to be a perfect illustration of what has been called by Beck "culinary cosmopolitanism" (2003, 37). Branding Dubai as cosmopolitan, without using the word itself, is part of a strategy of promoting it as a global city and fostering its economy as a site for practices of global consumption. If this consumerist face of cosmopolitanism has been internalized by the government, the other face of cosmopolitanism, segregation, is not overtly acknowledged, even though it is deeply embedded in the local urban order.

\subsubsection{Segregation as a Response to Cosmopolitanism?}

Segregation, usually presented as a key feature of Gulf Cities, is thought to be a way for citizens reduced to a demographic minority (except in Saudi Arabia and Oman) to keep foreigners out and preserve a cohesive national cultural identity (Gardner 2011; Khalaf 2006). In Dubai different types of segregation coexist. As a city with extremely fragmented urban planning, designed for the private car and with few public spaces, Dubai is marked by very high residential segregation. Segregation in Dubai is often analyzed through its most extreme urban forms: labor camps and gated communities (Kathiravelu 2016). The camps, mainly consigned to the outskirts of the city, are not open to the public. Despite this ban, photographers and journalists have regularly presented documentary evidence to denounce the miserable and insalubrious living conditions of the poorest foreigners, who are paid pitiful wages (from 600 to 1500 dirhams per month, 150-350 euros). Sonapur is one such camp. North of the city near the border with the neighboring emirate of 
Sharjah, Sonapur is hemmed in by the airport, the al Qusais industrial zone, a massive dump, and a cemetery. Although it is the most populated sector of the city with approximately 163,000 inhabitants, less than 100 women live there and there are no Emirati residents. At the other extreme, over forty gated communities occupy $7 \%$ of the built urban area (Elsheshtawy 2015). In the extremely luxurious Emirates Hill, built around a golf course, a contemporary villa with eight bedrooms and a pool costs 85 million dirhams (about 20 million euros).

These two urban forms must not overshadow other kinds of housing, however. With other colleagues, I have unpacked elsewhere the complex patterns of segregation in Dubai (Elsheshtawy et al. 2018), where extreme forms of segregations coexist with more mixed housing types. Low and mid-level wage earners commonly share accommodations. The numerous postings adorning walls and poles in some areas of Dubai are clear indicators that housing units are measured either by the room, partition, or bed space. ${ }^{4}$ They generally state preferences with regard to nationality, or even religion or regional origin, for future roommates. There are many such shared accommodations in the four or five-story 1970s-era buildings in the Bur Dubai and Deira neighborhoods. Another option is to seek out lower rents in less pricey neighboring emirates like Sharjah or Ajman, but at the cost of tiring commutes and heavy traffic jams.

The upper-middle classes often live in high-rise buildings in neighborhoods like the highly sought-after Marina. These high-rises often function as autonomous units with their own gyms and roof-top pools. While much more ethnically mixed, the residents are more socially homogeneous. In these high-rises and gated communities, income level is more determinative than national background. Segregation in Dubai among foreigners is thus more social than racial; for their part, nationals tend to relocate to peripheral neighborhoods built especially for them.

Another type of segregation present in Dubai is gender segregation. Initially developed as a component of a tribal Arab Muslim society, this practice concerns mostly the Emirati (or Gulf) population. Gender segregation seems to be declining for two reasons. Firstly, the dominant values of the Dubai cosmopolitan population favor more gender mixing. Second, the desire to modernize Emirati society through education and "Emiratize" the workforce to reduce dependence upon migrants requires the presence of Emirati women outside the home and interacting with men in the workplace.

Public (and some private) schools and universities usually segregate male and female students, but a recent law in 2018 introduced mixed-classes in public schools from grades 1 to 4 but kept separate classes beyond. Some restaurants have corners reserved for families that are off-limits to men dining alone. Some spaces (club, parks, beach) may be also reserved for use by women, temporarily (one day a week) or on a regular basis.

\footnotetext{
${ }^{4} \mathrm{~A}$ partition is a subdivision of a room in several tiny blind spaces with just enough space for a bed or bunk bed and a cupboard.
} 
After having focused on the nexus between consumption, segregation, and globalization its spatial translation can be understood by analyzing two cosmopolitan peripheral spaces, Global Village and International City. These two case studies help refine the analysis of cosmopolitanism by delving, at a local scale, into the interactions between globalization and consumption (Global Village) and between globalization and segregation (International City).

\subsection{Consuming and Experiencing the Diversity of the World in Global Village}

Shopping malls are places par excellence of cosmopolitan consumption. Far from the exuberant luxury of Dubai Mall, Global Village is a perfect expression of a "cheap" version of consumer cosmopolitanism, illustrating a real taste for "consuming" foreign places. Global Village is not necessarily found in traditional print tourist guides, but it appears as the fifth highest-rated destination on TripAdvisor. Open from November to April, Global Village is an outdoor "world-leading multicultural festival park," providing, as its website puts it, "world class cultural and family entertainment, along with a cosmopolitan and diverse shopping experience." Like many other places in Dubai, one day a week (in its case, Mondays) is reserved for families and women. In 2017-2018, Global Village's 10,000 exhibitors welcomed 5.6 million visitors, attracting as many tourists as residents and nationals. Besides a typical entertainment park (circus, carnival, Ferris wheel, shows), Global Village contains massive country and regional pavilions (Morocco, sub-Saharan Africa) representing about 75 countries. Each national pavilion features a fairly shoddy replica of an iconic monument; the Abu Simbel Temple, for instance, represents Egypt (Fig. 6.1). The world as represented in Global Village is not centered on the West but rather on the Middle East and Asia, which represented 15 and 7 of the 27 pavilions, respectively, for 2018-2019.

Each pavilion is supposed to sell products and food from the country it represents. Global Village is in reality a gigantic mall barely disguised by the effort to introduce visitors to world cultures. It offers low-quality, attractively priced goods, generally made in China, with sometimes little or no connection to the country in whose pavilion they are sold, especially in the case of the European countries. In the evening, a musical narrates the adventures of "Globo," the park's mascot, who has a giant head of multicolored hair symbolizing diversity. The park also hosts around twenty free concerts a year geared toward middle-class expats; in November 2018, there were concerts featuring the Moroccan-Egyptian singer Samira Said, the Yemeni Fouad Abdel Wahed, the Indian pop stars Neha Kakkar and Ankit Tiwari and the Filipina star Mayward.

The history of Global Village tells much about the history of the city, revealing two types of actors. First, it is closely linked with the launching of Dubai Shopping Festival in 1996 by Sheikh Mohammed al-Maktoum. Global Village belongs to 

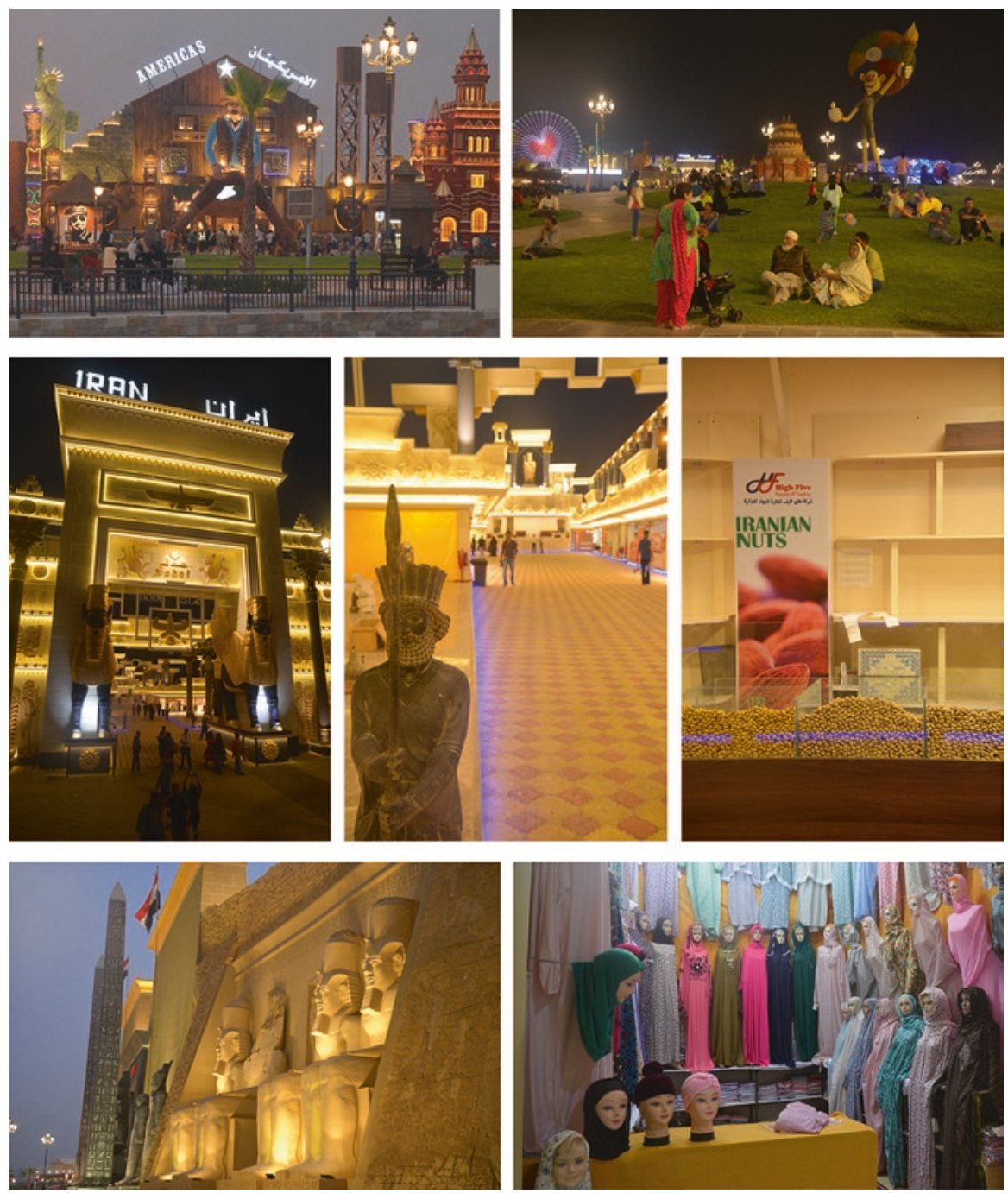

Fig. 6.1 Cosmopolitan landscapes in Global Village. (Source: Pagès-El Karoui, 1 November 2016)

Dubai Holding, property of the ruling emir. Global Village was started in 1996 from some kiosks located on Creek side, opposite Dubai Municipality, in the historical core of the city. It then moved to a more pericentral location, Oud Metha Area, near Wafi center, for five years. Since 2005, it has been in its current location on the outskirts of the city, with one of the biggest parking lots in Dubai (18,300 parking bays).

Global Village also reflects the prominent role played by the Indian community in the fabric of the global metropolis. The fate of Sunil Bhatia, a self-made man who arrived from Bombay in 1976 and worked first as a foreman and is now the owner 
of an entertainment company, is closely intertwined with the story of Global Village. ${ }^{5}$ He claims that the largest pavilion is the 11,000-square meter Indian one; it was also the first one erected, in 1996, with 20 stalls sponsored by the Indian government. While involved in the Dubai Indian Association, Bhatia played a major role in the Indian pavilion's organization. He then started to run it by himself, organizing for vendors from India to come for the five months of the year that Global Village is open. He has since extended his business by running the China and Europe pavilions. Indian products are sold mainly to Arabs and other tourists, but not to Indians who find them too expensive compared to what they can buy at home.

As to Global Village's customers, there are two things to mention. First, the Dh15 entrance ticket (each entertainment attraction inside costs extra) makes Global Village one of the few cheap places to go in Dubai, a city where each entertainment hot spot is very expensive, out of reach of the majority of residents. It is interesting to note that, in Global Village, the marketing of Dubai's diversity targets lower or middle classes. This is a far cry from a cosmopolitanism exclusive to an elite using it as a marker of distinction. Rather, Global Village represents a vernacular cosmopolitanism, as described by Pnina Webner (2006). Second, unlike most public spaces, Global Village is one of the few places in Dubai where visitors cross paths with many nationals, who are highly visible. Several newspaper narratives, spotlighting how Global Village epitomizes an inclusive place, emphasize the dissolution of social hierarchies:

There are people there of all nationalities, from all walks of life, representing the full gamut of Dubai's multicultural make-up; all of the city's perceived hierarchies seem to melt away. Literally and metaphorically, it is the common ground that is so often lacking in the UAE.

According to interviewees and Google reviews, visitors generally appreciate Global Village. Someone defining himself as a "white westerner" declares, "This is a very culturally diverse place (white westerners are $<5 \%$ ) and seems to be where everyone else in Dubai goes." Others write that "[the] World is here," speak of "a truly global experience," or indicate "having a lot of fun with my children. Surely visit again to explore more countries without Visa :)." The last quotation comes from an Indian man who appreciated his visit as a way to escape otherwise restricted mobilities in the world due to his passport. His experience in the theme park fulfills a desire to acquire worldliness and be modern by being a consumer of other cultures and places. This imagined cosmopolitanism conveys a desire to participate in global consumer culture, even if this participation is only symbolic. It is a perfect illustration of what Beck (2006) calls "banal cosmopolitanism."

Of course, some visitors are more skeptical: "It is a fraud program. U can't get experience and taste of different countries. It is full of business." These observations are in line with Molz's observation: "Cosmopolitanism often entails fantasies of

\footnotetext{
${ }^{5}$ Riyasbabu, "From Mumbai to Dubai in 1976", Khaleej Times, March 18, 2006. https://www. khaleejtimes.com/nation/general/from-mumbai-to-dubai-in-1976. Anjana Kumarn, "Global Village: Trip down memory lane", Gulf News, February 04, 2015. https://gulfnews.com/going-out/ society/global-village-trip-down-memory-lane-1.1451826
} 
transcending cultural differences, but consumerist ideology tends to reproduce the very social divisions cosmopolitanism claims to dissolve" $(2011,39)$.

These cosmopolitan landscapes, which may appear as "superficial" to critical eyes, are appropriated by many residents and tourists to fulfill cosmopolitan aspirations of being part of modern world society without necessarily being fooled by its artificial character. Global Village is a rare example of global consumption available to almost everybody (although the prices are not really cheap) in a city where practices of consumption are designed mostly for wealthy people. The same goes for accommodation. In another margin of the city lies an interesting area, Dubai International City, one of the few spaces designed for housing low and middle-class foreigners.

\subsection{Cosmopolitanism and Segregation in International City}

International City offers an original case-study for exploring the nexus between globalization and segregation in Dubai. Like Global Village, International City is part of a globalized imaginary that is reflected in its architecture with its desire to represent the diversity of the world. But it also expresses, with the emergence of the figure of the "bachelor" in Gulf cities, the extension of logics of segregation from national family to foreign family, from core areas to peripheral areas.

\subsubsection{A Cosmopolitan Suburban Community for Low- and Middle-Class Foreign Residents}

Dubai International City (DIC) is located in the outskirts of the city (one hour by bus from Deira, the historic center, or Burj Khalifa, the new center), between Al-Khor Industrial Area and a sewage treatment plant. Built by Nakheel and opened in 2007, it represents an interesting cosmopolitan landscape. ${ }^{6}$ It is one of the few real estate projects in Dubai designed from the outset to house foreigners with moderate incomes - most real estate projects in Dubai focus on upscale and luxury apartments and villas. The project blends studio and one-bedroom apartments in low-rise neighborhoods; it sits on one of the freehold areas where foreigners can buy land and property. International City has the lowest rents in Dubai (Elsheshtawy 2015): 600-700 AED for a bed space (lower beds are more expensive) and 1050 AED for a partition. While planned to house 60,000 persons, in 2018 it had 97,000 inhabitants, leading to serious problems with overcrowding. From the outside, the

\footnotetext{
${ }^{6}$ Funded in 2000, Nakheel is one the main real estate company belonging to Dubai Government, i.e., to the ruler. Its most famous realizations include artificial islands (the Palms, The World) and huge malls (Ibn Battuta, Dragon Mart).
} 
area has a bad reputation: weak infrastructure (incessantly overflowing sewers) and shoddy maintenance, pestilential odors from the neighboring sewage treatment plant, endemic prostitution, difficult access at peak hours and impossible parking day and night.

As elsewhere in Dubai, International City was designed as an enclave with little thought to its interactions within a larger environment. The design of the area may be surprising, as there are no street names, with buildings identified by letter and numbers (see Fig. 6.3). As a result, people constantly get lost and keep asking for directions. From the inside, though, International City may function for some residents as a real neighborhood, although many of them think of it as a bedroom community with minimal social interactions with one's neighbors. It is also one of the few places in Dubai, a city domination by cars, where people walk or bike (see Fig. 6.3).

The district is divided into ten clusters which bear country names: Greece, Italy, Spain, France, England, Russia, Morocco, Emirates, Persia, China (Fig. 6.2). Each cluster is supposed to reproduce the architectural styles emblematic of the eponymous country. Unlike Global Village, the world of International City is marked by a strong European tropism: six countries are European, three Middle Eastern and one Asian.

Some archetypal decorative elements are easily identifiable: the dome of Florence, Orientalizing domes for Persia, the Gothic windows with ogival arches for Venice (see Fig. 6.3). However, the distinctions are generally not very visible from one cluster to another and are sometimes limited to changes in the color of the building (grey for Russia, ochre for England). The composition of the population rarely coincides with the name of the district. There are almost no Westerners or Emirati living in International City. ${ }^{7}$ Its inhabitants are mainly Indians, Pakistanis, Filipinos, Chinese or Arabs.

The Chinese cluster is the only one where the country's name matches, partly, its population or shops. It has become a hub for the Chinese community in Dubai. One reason for its success is its location near Dragon Mart (opened in 2004, also by Nakheel), a huge cheap mall for wholesale and retail products from China. As the largest hub of Chinese products outside China, it has the reputation of having everything one could desire. Dragon Mart has a clientele from all the Emirates and even all of the Gulf (in the parking lot there are cars from Saudi Arabia or Oman). As proof of its popularity, an extension, Dragon Mart 2, was recently opened, and other expansions are under construction.

In the China Cluster, and more generally in International City, there are numerous stores and facilities displaying large signboards with Chinese characters: Chinese restaurants, clinics and a huge and busy supermarket, called Wenzhou, which offers a wide range of Chinese products, fresh fruit and vegetables, and even

${ }^{7} 150$ Emiratis lived in DIC in 2010, according to Dubai Statistics Center. 


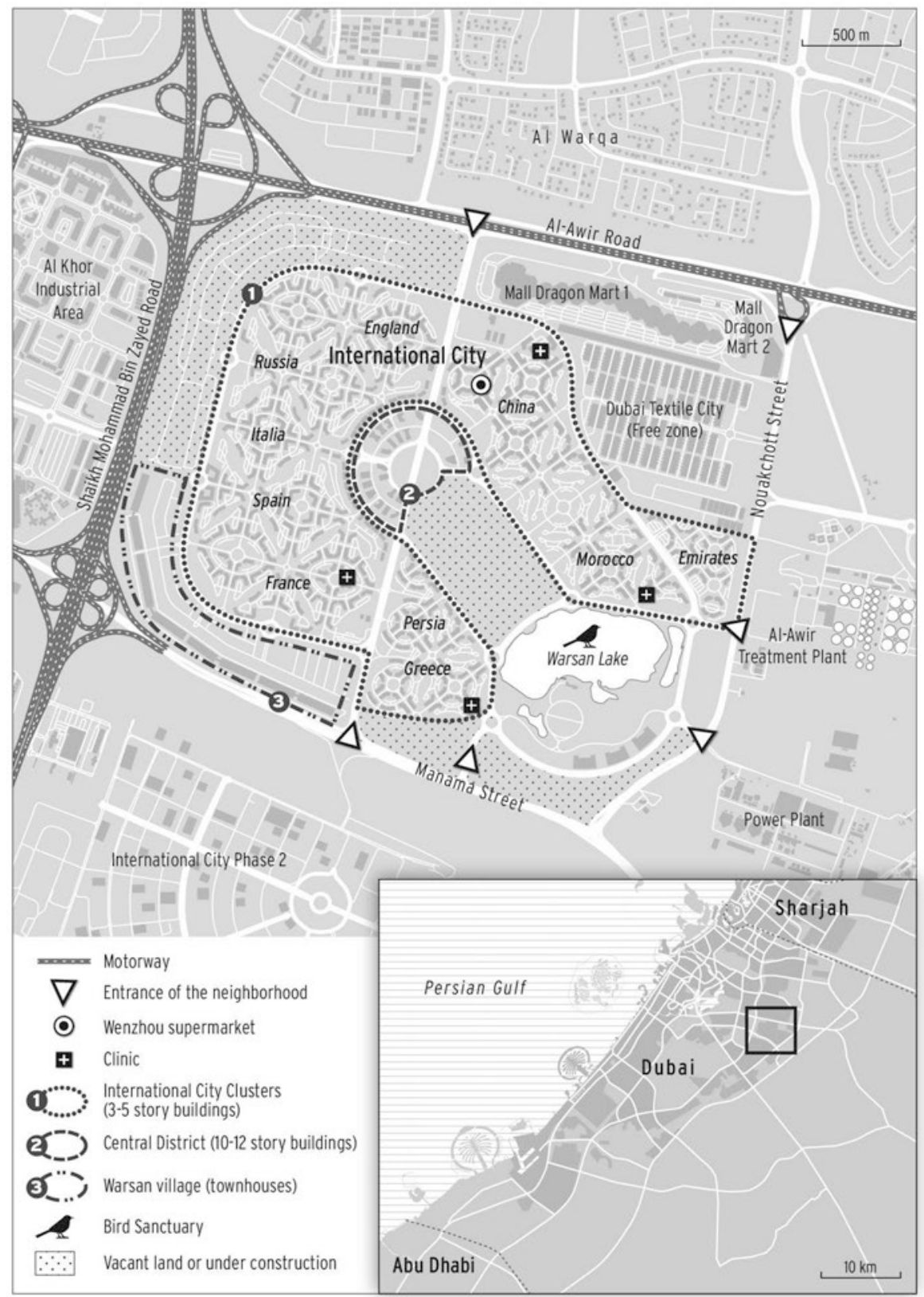

Fig. 6.2 Map of Dubai International City 

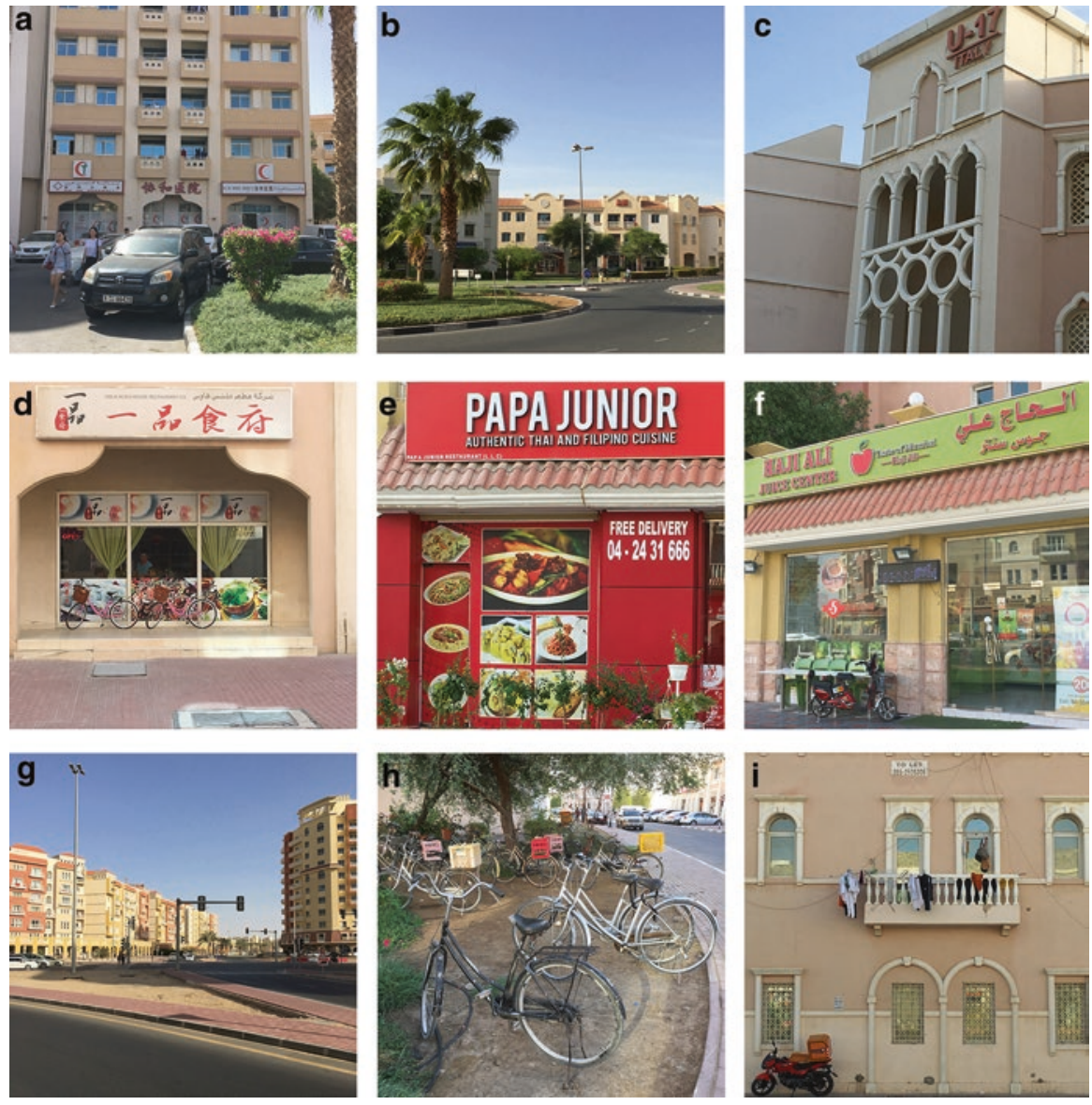

Fig. 6.3 Views of International City (2018). Legend: (a) Chinese pharmacy and medical center in China cluster; (b) Russia (left) and England (right) clusters; (c) Italian cluster; (d, e, f) Chinese/ Thai \& Filipino/Indian restaurants; (g) DIC CBD with high rise buildings and underground parking garages; (h) DIC is one of the rare areas of Dubai where bikes are widely used; (i) illegal hanging of laundry on balconies in the Italian cluster. (D. Pagès-El Karoui, October 2018)

pork (whose sale is very restricted in the UAE). ${ }^{8}$ Some customers complain about the fact that the labels are not in English. And indeed, someone can survive in the Chinese cluster without speaking English. If the Chinese cluster has become a hub for middle-class Chinese, it is still far from the model of an American Chinatown, having not yet become a tourist attraction. ${ }^{9}$

\footnotetext{
${ }^{8}$ Totally banned in Sharjah, pork can be bought in Dubai in several supermarkets in special sections dedicated to non-Muslims.

${ }^{9}$ Dubai won't stay long without a Chinatown since Emaar has announced in July 2018, during the visit of President Xi Jinping, its project to build a Chinatown inside the Dubai Creek Harbour Project.
} 
International City is usually presented in the Emirati press as cosmopolitan: "It is a world in one city in which people from an array of cultures and nationalities feel right at home". If a very limited cosmopolitanism emerges from its planned landscapes, a more tangible form emerges from the great diversity of its inhabitants. Due to its modest architecture and infrastructures and the low or middle income of its population, DIC epitomizes a kind of intermediary space, rare in Dubai, between the extreme forms of segregation found in labor camps and the luxurious environment of gated communities. But, like other parts of Dubai, even such ordinary spaces are worked over by processes of segregation, symbolized by the emergence of the intermediary figure of the "bachelor."

\subsubsection{The Extension of the "Bachelor" Threat or the "Ethos of Non-Mixing” in International City}

The category of the "bachelor," which is widespread in the Gulf urban imaginary, expresses the feeling that single male unskilled workers unaccompanied by their families (be they married or not) constitute a moral threat to the urban order. ${ }^{10}$ Consequently, the citizenry calls for their eviction from neighborhoods described as being restricted to families and asks that "bachelors" be segregated in a "bachelors accommodation" (Gardner 2011; Sarmadi 2013; Osella and Bristol-Rhys 2016). This public discourse, frequently disseminated in the media, is rooted in the overmasculinization existing in Gulf cities as a result of migration policies. With Doha in Qatar, Dubai holds another world record: its population is $70 \%$ male. ${ }^{11}$ This demographic imbalance is the result of how migratory flows are structured (a majority of men migrate alone to work in jobs, especially in construction, requiring few qualifications) and of policies restricting family reunification based on income. This over-masculinization is not evenly spatially distributed. Twenty-some neighborhoods have male residency rates over $90 \%$ while five neighborhoods do not have a single registered female inhabitant (Elsheshtawy et al. 2018). These neighborhoods are peripheral spaces that host camps of poorly qualified workers, primarily from South Asia, who live in extremely impoverished conditions.

The social type of the bachelor incarnates the "dangerous class" par excellence, threatening the urban order with unhealthy practices and intrinsic violence. The two main stereotypes see bachelors as threats to cleanliness and safety (especially for women and children). This discourse using a rhetoric of "invasion" is widespread

\footnotetext{
${ }^{10}$ This categorization, marked by a strong gender bias, entirely obscures the class dimension, and is furthermore inappropriate because many of these lone men are married but had to leave their wives back home.

${ }^{11}$ This imbalance was even stronger in 2010 , when women represented only $22 \%$ of the population. The city is thus in the process of re-feminizing with the arrival of many foreign women working as domestic help or in the service sector.
} 
worldwide among populations rejecting immigration. If the "bachelor" appears as an intermediary figure in the Emirates, it is because this category is mobilized when there is a risk of proximity between national families and working class-migrants. It applies to those unaccompanied male migrants living in the city, close to Emiratis, who work in service and technical jobs (Bristol-Rhys 2010). The migrants living in the labor camps appear less threatening because they are already segregated (Sarmadi 2013; Osella and Bristol-Rhys 2016).

According to Osella and Bristo-Rhys (2016), there is no "bachelor panic" in the Emirates (or at least in Abu Dhabi) because bachelors are not perceived as real men: they have been neutralized sexually and are therefore not regarded as socially dangerous. Without getting into a complex debate, I rather follow Sarmadi (2013) who has analyzed the various discourses in Dubai on the connections between "overcrowding" and "bachelor accommodation" that has proliferated since the early 2000s in the English-language Emirati press. An increasing number of Emiratis have been leaving the city's old neighborhoods to move to "new Dubai," freeing up lodgings, apartments, and houses that are in turn be rented by migrants sharing the accommodation, a process reminiscent of the suburbanization, white-flight, and ghettoization of American inner cities. The neighborhoods of old Dubai (Deira, Bur Dubai, and Karama), for instance, are becoming majority Asian and are now perceived by Emiratis and middle to upper-class "expats" as densely packed and seedy.

Developing under the control of big groups, New Dubai has gotten away from the influence of the municipality, which intends to keep control over the oldest parts of the city. In 2008 the municipality launched an inspection campaign entitled "One villa, one family" to survey lodgings that have been divided up to maximize rental income and house a large number of foreign workers. Heavy fines are imposed on delinquent owners and water and electric services are cut until they comply. These evictions are conducted under the pretext of health and safety in order to preserve the (Emirati) "families" remaining in the neighborhood. International City was built in this context with the purpose of offering affordable accommodation to lowincome migrants who were forced to share apartments or villas in the inner city.

The scholarly literature seems to limit these antagonisms between bachelors and families to the inner city and national households (Gardner 2011; Sarmadi 2013; Osella and Bristol-Rhys 2016). But similar campaigns were repeated a few years later in desert neighborhoods on the edges of the city and also in International City, by Trakhees, the regulatory authority for freehold areas. Rents in the neighborhood had plummeted by $80 \%$ after the 2008 financial crisis, when Dubai was saved in extremis from near bankruptcy by Abu Dhabi. These drop-in rents attracted workers who preferred to live 6-10 people per studio rather than a labor camp. At the same time, the lower rents also spurred families to move elsewhere, so this now unoccupied housing was rented out to "bachelors." Meanwhile, the Nakheel company was also going through rough times, which made it less attentive to the neighborhood and infrastructure maintenance. The growing density caused by accommodation sharing leads to significant parking and access problems, depletes the local environment, and leads longer-term residents to decry the "invasion of bachelors," whom 
they accuse of being dirty, noisy, and threatening the neighborhood peace (women and children are said to no longer dare go into the street).

Following a news article presenting International City as a "squalor township," an Internet debate emerged about evicting bachelors from the area. Some residents proclaimed that unless something is done, International City will become "another Sonapur," a "bachelor city," a "shantytown city," or a "city of crime": "If they do not segregate bachelors from families, this place will become a total labour camp." 12 These inhabitants, who were upset to not have received any answers to their complaints to Nakheel, clearly present an "ethos of non-mixing." 13 They have assimilated Dubai's segregated urban order which distinguishes between areas for families and areas for "bachelors." Other readers, who seem to belong to a higher class and do not live in DIC ("living in Dubai Marina like you and me"14), defend the laborers and shift the discussion to the lack of cheap accommodation available to workers.

So the novelty brought by the case of International City is two-fold. First, the category of "bachelors," which initially developed as a threat to Emirati families, has become a threat to foreign middle-class residents; second, the eviction of bachelors, which initially concerned the inner city, has been extended to the peripheries. The fear of "bachelors" and the claim for more segregation thus becomes an anxiety shared by middle and upper classes beyond national differences. Should this be seen as a sign of integration into a common local urban culture in a country which denies assimilation?

\subsection{Conclusion: Thinking Cosmopolitanism Empirically from Dubai Ordinary Spaces}

One of the challenges of this book is to think cosmopolitanism outside the framework of normativity and to unravel how cosmopolitanism is grounded in specific times and urban spaces. This chapter has tried to show how Dubai, analyzed through two ordinary spaces, may be a valuable case study by broadening the base of cosmopolitanism to the low and middle-classes and to non-Western cities. Dubai embodies multiple meanings of cosmopolitanism in terms of both a cultural dimension of globalization and the coexistence of a heterogeneous population. Its cosmopolitanism, in a deeply unequal society, intertwines three main features: consumption, segregation, and globalization. In its quest for global visibility and status, the Dubai

\footnotetext{
${ }^{12}$ All these quotations are found in the readers' comments following the paper « International City: Squalor township », by Jay B. Hilotin, 24 Feb. 2011, Gulfnews, https://gulfnews.com/business/ property/international-city-squalor-township- 1.766738

${ }^{13} \mathrm{I}$ 'm building this expression, inspired by Susanne Wessendorf (2013)'s work on Hackney, a super-diverse area in London. She uses "ethos of mixing" to describe residents' positive attitudes towards diversity and the difficulties they have to understand people who do not want to mix.

${ }^{14}$ Dubai Marina is a expansive area when a lot of wealthy expats live, near the beach in high rise buildings, viewing a marina.
} 
government promotes a friendly and positive image of diversity. It encourages, through its own real estate companies, the construction of cosmopolitan landscapes that cater to a global taste for consuming foreign places. But this extreme consumer society is only accessible to its richest residents. Similarly, urban space is highly segregated. This does not exclude pockets of high mixing of nationalities who generally belong to the same social milieu.

To unpack Dubai's complexity and to de-exceptionalize its glamorous image, I have chosen to present two ordinary spaces which have not yet been studied and are far less famous than Dubai's iconic spaces. For both Global Village and International City, their names convey an image of worldliness and their built environment plays on the representation of global diversity. They represent two forms of Dubai's cosmopolitan urbanism, built at its peripheries and frequented mainly by nonWesterners. Global Village, the gigantic open-air park and mall selling products from all over the world, epitomizes the commodification of difference, where cosmopolitanism is performed as a form of global consumption and where logics of inclusion prevail. International City is one of the few housing developments on the freehold area accessible to low and middle-income immigrants in a city in desperate need of cheap housing. When rents fall and infrastructure and physical environments deteriorate, fears rise among "families" and state agencies about "bachelors" invading the neighborhood, leading to overcrowding, filth and insecurity. This bachelor/family divide is a common feature of segregation in Gulf cities, but the novelty is the extension of the logics of exclusion from Emirati families to middle-class foreign residents, from inner city to peripheral areas.

In light of these two ordinary spaces, Dubai embodies a new urban formulation of cosmopolitanism with all its contradictions, the concomitant logics of inclusion and exclusion. While certainly far from its original normative dimension, this complex form of cosmopolitanism is very enlightening to understanding the future logics of the new global urban order.

\section{References}

Assaf, L. (2017). Le shopping mall comme moment urbain.Pratiques citadines et transformations des espaces marchands aux Émirats arabes unis. Ateliers d'anthropologie 44 (online).

Bayat, A. (2008). Everyday cosmopolitanism. Isim Review, 22, 5.

Beck, U. (2003). Conversations with Ulrich Beck, with J. Willms. Polity: Cambridge.

Beck, U. (2006). Cosmopolitan vision. Cambridge: Polity.

Binnie, J., Holloway, J., Millington, S., \& Young, C. (2006). Cosmopolitan Urbanism. London/ New York: Routledge.

Bristol-Rhys, J. (2010). « A Lexicon of Migrants in the United Arab Emirates (UAE) ». Middle East Institute Viewpoints: Special Edition, 24-6

Davidson, C. M. (2008). Dubai: The vulnerability of success. New York: Columbia University Press.

Delanty, G. (2009). The cosmopolitan imagination. Revista CIBOB d'Afers Internacionals, 82-83, 217-230.

Elsheshtawy, Y. (2013). Dubai: Behind an urban spectacle. London: Routledge. 
Elsheshtawy, Y. (2015). Macro Dubai: Quantifying urban growth. Urban Research Lab (UAEU), UAE.

Elsheshtawy, Y. (2019). Temporary cities: Resisting transience in Arabia. Milton Park Abingdon: Routledge.

Elsheshtawy, Y., Pagès-El Karoui, D., \& Bahoken, F. (2018). Mapping patterns of segregation in Dubai: towards a new research agenda for a social geography of Gulf Cities. Paper presented at the conference Migrants in the Globalizing City: Spaces, Places and Mobilities in Asia, Europe and the Middle East, Paris, July 9-10.

Gardner, A. M. (2011). Gulf migration and the family. Journal of Arabian Studies, 1(1), 3-25.

Kanna, A. I. (2011). Dubai, the City as corporation. Minneapolis: University of Minnesota Press.

Kathiravelu, L. (2016). Migrant Dubai: Low wage workers and the construction of a Global City. Basingstoke: Palgrave Macmillan.

Khalaf, S. (2006). The Evolution of the Gulf City Type, Oil, and Globalization. In J. W. Fox, N. Mortada-Sabah, \& M. al-Mutawwa (Eds.), Globalization and the Gulf (pp. 244-265). London: Routledge.

Khalaf, A., AlShehabi, O., \& Hanieh, A. (2014). Transit states: Labour, migration and citizenship in the Gulf. London: Pluto Press.

Lamont, M., \& Aksartova, S. (2002). Ordinary cosmopolitanisms: Strategies for bridging racial boundaries among working-class men. Theory, Culture \& Society, 19(4), 1-25.

Latham, A. (2006). Sociality and the cosmopolitan imagination: National, cosmopolitan and local imaginaries in Auckland, New Zealand. In J. Binnie, J. Holloway, S. Millington, \& C. Young (Eds.), Cosmopolitan Urbanism (pp. 89-111). London: Routledge.

Longva, A. N. (2005). Neither autocracy nor democracy but ethnocracy citizens expatriates. In P. Dresch \& J. P. Piscatori (Eds.), Monarchies and nations: Globalisation and identity in the Arab states of the Gulf (pp. 114-135). London: I. B. Tauris.

Masad, M. (2008). Dubai what cosmopolitan city? Isim Review, 22, 10-11.

Molz, J. G. (2011). Cosmopolitanism and consumption. In M. Rovisco \& M. Nowicka (Eds.), The Ashgate research companion to cosmopolitanism (pp. 33-52). London: Routledge.

Nava, M. (2002). Cosmopolitan modernity: everyday imaginaries and the register of difference. Theory, Culture \& Society, 19(1-2), 81-99.

Osella, C., \& Bristol-Rhys, J. (2016). Neutralized Bachelors, Infantilized Arabs: Migrant and Host Gendered and Sexual Stereotypes in Abu Dhabi. In N. Lindisfarne \& A. Cornwall (Eds.), Masculinities under Neoliberalism (pp. 111-124). London: Zed.

Pagès-El Karoui, D. (2018). Cosmopolitisme et ségrégation à Dubai. Urbanisme, 409, 64-67.

Pagès-El Karoui, D. (2021a). Cosmopolitan cities. In V. Cicchelli \& M. Sylvie (Eds.), Cosmopolitanism in Hard Times (pp. 192-204). Leiden: Brill.

Pagès-El Karoui, D. (2021b, forthcoming). Ambivalent cosmopolitan narratives in Dubai: Forging landscapes of tolerance and happiness in a global city. City, 25(1-2).

Retaillé, D. (2012). Les lieux de la mondialisation. Paris: le Cavalier bleu.

Robinson, J. (2013). Ordinary cities: Between modernity and development. London: Routledge.

Sarmadi, B. (2013). 'Bachelor' in the City: Urban transformation and matter out of place in Dubai. Journal of Arabian Studies, 3(2), 196-214.

Vora, N. (2013). Impossible citizens: Dubai's Indian diaspora. In Durham. London: Duke University Press.

Webner, P. (2006). Vernacular cosmopolitanism. Theory, Culture \& Society, 23(2-3), 496-498.

Wessendorf, S. (2013). Commonplace diversity and the 'Ethos of Mixing': Perceptions of difference in a London neighbourhood. Identities, 20(4), 407-422.

Yeoh, B. S. A. (2004). Cosmopolitanism and its exclusions in Singapore. Urban Studies, 41(12), 2431-2445. 
Open Access This chapter is licensed under the terms of the Creative Commons Attribution 4.0 International License (http://creativecommons.org/licenses/by/4.0/), which permits use, sharing, adaptation, distribution and reproduction in any medium or format, as long as you give appropriate credit to the original author(s) and the source, provide a link to the Creative Commons license and indicate if changes were made.

The images or other third party material in this chapter are included in the chapter's Creative Commons license, unless indicated otherwise in a credit line to the material. If material is not included in the chapter's Creative Commons license and your intended use is not permitted by statutory regulation or exceeds the permitted use, you will need to obtain permission directly from the copyright holder. 